\title{
Comparison of Male and Female Differences in Emotional Intelligence Among Trained Univerisities Athletes of Lusaka Province, Zambia
}

\author{
Mathivanan D \& Clement chileshe
}

\section{St.Eugene University, Zambia}

Director, Olympic youth Development centre, Assistant Professor

E-mail: gokulvarshan2004@gmail.com

Abstract. (Palmer and Stough 2001) defined as Emotional intelligence as 'the capacity to deal effectively with one's own and others' emotions 'Previous empirical studies in this area have indicated that the construct of emotional intelligence provides an athlete with an understanding of their specific emotional competencies, and therefore a better understanding and awareness of how to use emotions in sport. The comparison of the study is to attempt and examine the differences between female and male athletes of Lusaka Province with respect to their emotional intelligence in the selected variables such as Self-awareness, Self-regulation, Motivation, Empathy, Social skills.

It was assumed that female athletes would have high emotional intelligence as compared to the male athletes. "Emotional Intelligence Test" developed by Dr. N. K. Chadha (1998) was applied on all of the participants of the study (i.e. 30 female and 40 male athletes).Were selected random for this study Statistical analysis by computation of "t-test" revealed a significant difference in the emotional intelligence of female and male athletes of Lusaka Province. The results confirmed the hypothesis differences in relation to emotional intelligence, findings of the current study indicate that females are more emotionally intelligent than male athletes. The higher level of emotional intelligence of female than male in Lusaka Province are explained in terms of traditional trends, pattern of society and social roles assigned to male and female with respect to African culture in Zambia.

Keywords: Emotional; Intelligence; Athletes; Male; Female.

\section{Introduction.}

Until recently, the role of emotional intelligence in performance had primarily been studied within the corporate environment or the workplace. Such research has indicated that individuals with better emotional intelligence typically perform with greater success than individuals who have less effective ways of dealing with emotions. As most people would agree, the 'workplace' of the elite athlete is both the competitive and training environment, yet it is during competition that an athlete's performance is ultimately evaluated.

Like IQ or heart rate, emotional intelligence is a measurable concept. Recent research at South Australian Sports Institute has found that emotional intelligence is best assessed within the competitive sporting environment using a General Sporting version of the Swinburne University Emotional Intelligence Test. A self-report measure, the General Sporting version of the Swinburne University Emotional Intelligence Test, consists of 64 statements related to how the individual recognises, expresses and understands their emotions during athletic performance.

In a recent study, we looked at emotional states associated with success and failure in sport competition and academic examinations (3). The expansion of sport science as an academic study means that growing numbers of students experience the dual stresses of taking examinations and participating in competition. The results of this study are depicted in figure 1 which shows that a) emotions are strongly associated with success, and b) emotional profiles linked with success are somewhat different between sports competition and an examination.

Compared to exams, success in sport was associated with vigour and anger. Importantly, emotionally intelligent people can get themselves into the appropriate emotional states for the demands of the situation. If the situation requires high arousal, as in the case of athletes in our study, emotionally intelligent people are good at getting themselves psyched up. Equally, if the situation requires calmness, emotionally intelligent people are good at relaxing themselves.

Our research group has conducted a number of studies looking at the nature of emotional intelligence (4). We have found that emotionally intelligent people use psychological skills such as imagery, goal setting and positive self-talk more often than their less emotionally intelligent 
counterparts. We have found that emotionally intelligent people are mentally tough and also that they find exercise enjoyable. Importantly, it seems that emotional intelligence can be enhanced through suitably developed intervention packages. What follows is a six-stage approach to assessing and implementing strategies that people can use to enhance their emotional intelligence:

The capability to change emotional states and learning how to change emotions in relation to performance requires self-awareness. We need to be able to identify when our emotions are influencing our performance and how our emotions change over time. We need also to be able to assess the emotional states that other people are feeling, picking up on their body language, verbal and non-verbal gestures.

There are many possible ways in which to assess emotions, including standard psychometric tests; however, athletes often find repeated completions of standardised scales to be a tiresome task. An alternative approach is to use an open-ended diary type approach such as a video or an audio diary. Assessment of emotions should start by asking the athlete to think carefully about a situation in which performance was very important. It helps if the athlete spends some time rehearsing this situation in their mind, and tries to remember how they felt. The athlete then writes down all of the emotions they experienced. They should also rate how they performed in the situation to allow comparisons between successful and unsuccessful performance.

A Cockerill (2002) state that sports today places considerable demands on performers and requires the support for specialists to facilitate the integration of mind and body, especially to achieve success as a professional athlete. In this regard, sport psychology is available to athletes for useful advices and support. Psychological factors are recognized as having an important part to play in the attainment of success in sport. It is also recognized that sport psychologists can help to make the difference between winning and losing. Thus, the demand for psychological services in sport is increasing.

Emotions such as anxiety can be positive and negative. It is the combination of emotions, and the thoughts that are linked with these combinations that determines whether these emotions are motivational or de motivational could be useful among the athletes to enhance the performance.

\section{Statement of the Problem:}

A sport psychologist, Lauther (1972) discovered that most studies of male athletes report them to rank high in such traits as self-confidence, extroversion, leadership, dominance, emotional maturity, social poise, having high level of aspiration and consideration for others. Whereas, female athletes seem to differ from male athletes only in concern for their self-image (in this case, a desirable feminine image); and in their sensitivity to male social attitudes toward female's athletic participation female athletes are more concerned with appearance and aesthetic aspects in sports.

In light of the sport psychologists views as mentioned above it can be believed that professional athletes belonging to both sexes have few differences in respect of their personality traits and qualities and hence, their level of EI may be different. Thus, keeping in mind all the above considerations the present study is aimed to evaluate differences in EI of males and females athletes in various universities athletes of Lusaka Province. Thus the purpose of the study is the comparison of male and female differences in emotional intelligence among trained universities athletes of Lusaka province, Zambia

\section{OBJ ECTIVES OF THE STUDY:}

The objective of the study is to understand the differences between the male and female universities athletes and their emotional intelligence; therefore the following objectives are framed to investigate the study.

1. To find out the level of emotional intelligence of a sample male and female universities athletes in Zambia

2. To find out the of level of emotional intelligence with respect to the component Selfawareness, Self-regulation, Motivation, Empathy, Social skill

3. To find out whether there is gender difference in emotional intelligence.

4. To find out gender difference, if any, in the components of Emotional Intelligence: Selfawareness, Self-regulation, Motivation, Empathy, Social skill

\section{HYPOTHESIS OF THE STUDY:}

- There is no significance difference in the EI mean scores between the males and the females athletes in the Lusaka province universities 
- There is no significance difference in the mean scores on components of EI sub-skills between the males and the female athletes in the Lusaka province universities

\section{DELIMITATION:}

- The study is limited among the universities situated in Lusaka province

- The study is investigated in an athletic competition on republic day celebration of Zambia

- The subject were selected randomly 40 male and 30 female Universities athletes under the age group of 20 to 35

\section{REVIEWS OF RELATED LITERATURE}

Zamanian et al. (2011) comparison of emotional intelligence in elite athletes in several sports and non-athletes. For that matter, 160 women including 90 handball, futsal, and basketball players participating in 2009-2010 premier league (30 women in each group) and 70 non-athletes filled out the BarOn Emotional Quotient Inventory (EQ-i). This questionnaire consists of 15 subscales for an overall assessment of emotional intelligence. The results of statistical analysis showed that the subscales of problem solving, happiness, independence, stress tolerance, self-actualization, emotional self-awareness, interpersonal relationship, optimism, self-regard, impulse control, and empathy were significantly higher in athletes than non-athletes.

Bal et al. (2011) investigation was to determine if there are cognitive psychological factors used in competition and training which differentiate athletes participating in an open and closed skill sport. A total of 40 inter-varsity athletes $(n=20$; footballers) from open-skill and ( $n=20$; gymnasts) from closed-skill sports completed the emotional intelligence questionnaire (EIQ16). The EIQ16 measures 16 emotional competencies covering the ability to accurately perceive emotions in one-self and others, use emotions to facilitate thinking, understand emotional meanings, and manage emotions. Student's t-test for independent data was used to assess the between-group differences. Accordingly, interest in emotional intelligence has increased specifically in the realm of athletics (Zizzi et al., 2003). Proponents have claimed that emotional intelligence can enhance leadership performance, team cohesion, and coping with pressure.

Palmer et al. (2007) Since Salovey and Mayer's (1990) seminal article on emotional intelligence (EI), a number of alternative models have been developed (e.g., Bar-On, 1997; Cooper \& Sawaf, 1997; Goleman, 1995; 1998; 2001a; Mayer \& Salovey, 1997; Petrides \& Furnham, 2001). This work has provided different approaches to the conceptualization and measurement of EI. However, it has also caused some confusion concerning the nature and boundaries of the concept. Variables ranging from emotional abilities and competencies, to so-called 'noncognitive'capabilities and skills have been placed under the banner of EI.

Shinde (2011) The main purpose of the study is to investigate difference between Emotional Intelligence, Self-confidence of students in terms of type of education i.e. professional and nonprofessional. For this investigation two groups were selected for professional students $(\mathrm{N}=50)$ and non-professional students $(\mathrm{N}=50)$ from Aurangabad city. The research tools are Emotional Intelligence scale (Hyde, Pethe, and Dhar), Self-confidence Inventory. (Basavanna) were used, and ' $\mathrm{t}$ ' test was applied to check the difference between two groups. The result obtained through the study do showed significant difference between Emotional Intelligence, but shows significant difference on Self-confidence of students in terms of type of education i.e. professional and nonprofessional.

Dev et al (2012) As we all know the benefits of physical activity (PA) on physical and mental health are well established. However, inactivity among adults in Malaysia is still prevalent. This study examined whether emotional intelligence (EI) was one of the possible underlying psychological mechanisms that may be associated with the current low levels of PA adherence. Therefore, the purpose of the study was to examine whether EI plays a role as the potential underlying mechanism of PA behaviour among Malaysian adults. A total of 172 supporting staffs were recruited at a local Malaysian university. It was found that supporting staffs with higher physical activity in a week had better total EI scores and composite subscale scores. The findings of this study provide further support on the claims that there is a positive relationship between increased levels of EI and physical activity. Thus, the importance of higher emotional intelligence is critical in helping to bombard the sedentary lifestyle and inactivity among Malaysian adults. 
Antonakis et al. (2009) Interest in emotional intelligence has bloomed over the last few Years. That it has become a popularity standard concept in general and applied psychology as well as in applied business settings is indubitable. Is this popularity warranted? Casting a shadow over the concept of emotional intelligence is concern about its meaning fullness and the construct and predictive validity of its various measures. The following series of letters explores various issues surroundings emotional intelligence and leadership including whether emotional intelligence is theoretically needed for leadership, the types of emotional intelligence test that may hold the most promise, methodological standards for testing whether emotional intelligence matters, evidence from the neuroscience literature on emotion and intelligence, and evidence regarding the links between leader emotional intelligence and follower out come.

Dominikus et al. (2009) this research was carried out to exile the relationship between mental skills and anxiety interpretation in secondary school hockey athletes. There are 108 participants ( 54 males, 54 females)aged between 14 and 17. These participants are athletes from three secondary schools. The average age of the participant is $15.17(\mathrm{SD}=1.18)$ The results indicated that the direction of anxiety interpretation between the male and female athletes are the same but different in terms of intensity (cognitive anxiety interpretation direction, somatic anxiety and self confidence)

Nawi (2011) studied the main objective of this cross-sectional study is to determine the differences characteristic between volunteers and non-volunteers in terms of emotional intelligence, self-esteem and personality based on four dimension aspects of personality such as psychoticism, neuroticism, extraversion and lie. Three sets of questionnaire to measure Emotional Intelligence, Self-Esteem and Personality were administered to 276 subjects. One hundred and sixty eight of them were volunteers and one hundred and eight were nonvolunteers. Findings showed that there was no significant difference between volunteers and non-volunteers in term of emotional intelligence $(t=0.13, p>0.05)$

\section{RESEARCH DESIGN:}

\section{METHOD:}

The subjects were selected from different athletes participated in the catholic students association athletic competitions from various universities in Lusaka, Zambia. A total of 70 athletes (40 male and 30 female athletes aged 21 to 37 years were selected from the competition all the athletes were selected through random sampling.

\section{TOOL}

The Emotional Intelligence (EI) Test developed by Dr. N.K. Chadha (a psychologist at the university of Delhi, India) was used. The test consists of fifteen emotional contexts with four near emotionally intelligent responses. The fifteen situations categorized into five emotional sub skills such as 'self awareness', 'self regulation', 'motivation', 'empathy' and 'social skill' are listed in Appendix-I. The highly emotional intelligent subject would get a score of 20 and the lower brackets are scores of 10, 5 and 0 . The situations are designed to assess one's ability to succeed in coping with environmental demands and pressures. The sum of the scores on the responses to the entire range of fifteen situations will be interpreted as 'extremely high' (285 and above), 'high' (from 250 to 284), 'average' (from 176 to 249), 'below average' (from141 to 175).

\section{Analysis of Data and Interpretation:}

The collected data were analyzed and interrupted in below indicated tables

Table 1: Level wise Distribution of Emotional Intelligence

\begin{tabular}{|l|c|c|c|}
\hline \multicolumn{1}{|c|}{ Level } & Male athletes & Female athletes & Total \\
\hline Extremely High & 0 & 0 & 0 \\
\hline High & 4 & 2 & 6 \\
\hline Average & 24 & 16 & 40 \\
\hline Below Average & 12 & 12 & 24 \\
\hline Total No. of subjects & 40 & 30 & 70 \\
\hline
\end{tabular}

Table 1 indicates that tightfisted four male and two female in the High level (0.8\%) subject all the subjects in this sample fall Under average 40 subjects (56\%) with the split up of 24 male (34\%) 
and 16 female (22\%) the subjects in this sample fall average and 24 subjects (34\%) with the breakup of 12 male (17\%) and 12 female (17\%) subjects fall in the below average' category.

Table 2: Gender-Wise Distribution of Emotional Intelligence

\begin{tabular}{|l|c|l|c|c|c|c|}
\hline Gender & $\begin{array}{l}\text { No. of } \\
\text { subjects }\end{array}$ & $\begin{array}{l}\text { Mean EI } \\
\text { Score }\end{array}$ & SD & SE & “t” & $\begin{array}{c}\text { “t” critical } \\
\text { value two tail } \\
\text { at 5\% level }\end{array}$ \\
\hline 1 & 2 & 3 & 4 & 5 & 6 & 7 \\
\hline Male & 40 & 90.69 & 12.09 & 2.02 & -2.34 & 1.96 \\
\hline Female & 30 & 112.47 & 9.20 & 3.45 & & \\
\hline Total & 70 & 99.79 & 12.49 & 1.98 & & - \\
\hline
\end{tabular}

The mean EI score of this sample (99.79) indicates that it falls in the category of 'average' (as per the norm given by Dr. N.K. Chada). The gender based EI scores also describe both the male and female in this sample as "emotionally average". The coefficient of variation discloses higher consistency in the response of the female (22\%) than in the male (34\%) in this sample. However, the difference of 9.43 in the mean score between males and females is found to be statistically significant. The calculated ' $\mathrm{t}$ ' value -2.34 is greater than the critical value 1.99 at $5 \%$ level of significance. It is inferred that the females evince higher emotional competency compared to the males.

Table 3: Gender-Wise Distrbution of the Scores on the Components of ei

\begin{tabular}{|l|l|l|l|l|l|l|}
\hline \multicolumn{1}{|c|}{ Gender } & \multicolumn{2}{c|}{ Male } & \multicolumn{2}{c|}{ Female } & \multicolumn{2}{c|}{ Total } \\
\hline Self-awareness & 26.12 & 5.12 & 32.47 & 2.20 & 23.12 & 2.76 \\
& & & & & & \\
\hline Self-regulation & 12.15 & 3.14 & 28.10 & 1.38 & 22.36 & 2.02 \\
\hline Motivation & 30.10 & 2.16 & 23.60 & 2.25 & 30.46 & 4.06 \\
\hline Empathy & 16.20. & 1.36 & 20.20 & 2.76 & 13.20 & 1.70 \\
\hline Social skill & 24.12 & 1.41 & 18.10 & 2.81 & 11.30 & 1.95 \\
\hline Total & 98.69 & 12.09 & 112.47 & 9.20 & 99.79 & 12.49 \\
\hline
\end{tabular}

Table 3 reveals that in all the five components the universities athletes fall under "average' category. The component 'motivation' ranks first with a mean score of 30.46 and 'Social skills' ranks last with a mean score of 11.30. The females in this sample show lead over the males in all the three components.

\section{Findings, Conclusion \& Recommendation \\ Findings}

The mean score of the sample as a whole falls under 'average' EI category as per Chadha's norms: $56 \%$ fall under 'average' emotional intelligence category, 34\% in the below average' and just two female and two male student in the 'high' emotional intelligence category. Among males and females $34 \%$ and $22 \%$, respectively come under 'average' and males $17 \%$ and female $17 \%$ comes under 'below average' emotional intelligence category

The females in this sample evince higher emotional competency (with the mean score, 112.47) compared to the males (with the mean score 90.69), when faced with emotionally challenging situations.

The mean scores on all the five components indicate a lead in the females over the males.

The mean difference between male and female is statistically significant with respect to 
'motivation' and 'social skill' .The mean score on 'Motivation' is the highest and the mean score on 'social skill' is the lowest.

\title{
Conclusion
}

The highest level of emotional intelligence among the universities athletes in the Lusaka province of Zambia The 'average' level of emotional competency indicates that these students lack emotional competency essential for performing in the sports competition which includes their career personally successful and socially meaningful.

It also includes the training of emotional intelligence in the curriculum and also in coaching the athletes that can help the athletes to gain emotional competency.

\section{Recommendations}

Further research can be done in the same topic with different samples and different game situations. It could be useful to the coaches and athletic trainers of both gender in identifying the areas in which more efforts needed in developing the athletes.

\section{References:}

1. Antonakis, John; Ashkanasy, Neal M. and Dasborough, Marie, T. (2009). Does leadership need emotional intelligence. ELSEVIERJ ournal Quarterly. 20, 247-261.

2. Bal1, Baljinder, Singh; Singh, Kanwaljeet; Sood, Manu and Kumar, Sanjeev (2011). Emotional intelligence and sporting performance: A comparison between open and closed skill athletes. J ournal of Physical Education and Sports Management. Volume. 2 (5), pp. 48-52.

3. Dev, Roxana, Dev, Omar (2012). Emotional intelligence and physical activity among suporting staffs at a malaysian university. Clute Institute International Conference..

4. Dominikus, Filino;an, Fauzee, Mohd, Sofi, Omar; Abdullah, Maria, Chong; Meesin, Charoon and Choosakul, Chairat (2009). Relation between mental skill and anxiety interpretation in secondary school hockey athletes. European J ournal of Social Sciences. Volume 9, No. 4.

5. Nawi, Nurul Hudani Md (July 2011). Emotional Intelligence, Personality and Self Esteem: A Comparison of the Characteristics among Two Categories of Subjects. International J ournal of Humanities and Social Science, Vol. 1 No. 8.

6. Palmer, Benjamin R.; Gignac, Gilles; Ekermans, Gina and Stough, Con (2007). A Comprehensive Framework For Emotional Intelligence. Nova Science Publishers, Inc.

7. Shinde, Ravinde (2011). A comparative study of emotional intelligence \& self confidence of professional \& non professional college students. Social Growth. Volume II, Issue II. Pp. 86

8. Zamanian1, Faezeh; Haghighi, Mina; Forouzandeh, Elham; Sedighi, Zahra and Salehian, Mir Hamid (2011). A comparison of emotional intelligence in elite student athletes and non athletes. Annals of Biological Research. 2 (6):179-183.

\section{Сравнение различий между мужчинами и женщинами в области эмоционального восприятия среди университетских спортсменов провинции Лусака, Замбия}

\author{
Матхиванан Д. клементчилеше
}

Сант Евген университет, Замбия

Директор Олимпийского центра развития молодежи, доцент

E-mail: gokulvarshan2004@gmail.com

Аннотация. (Палмер и Стафф 2001) определили эмоциональное восприятие как «способность эффективно управлять своими и чужими эмоциями». Предыдущие эмпирические исследования в данной области определили, что развитие эмоционального восприятия дает спортсмену понимание собственных эмоциональных возможностей, и, как следствие, лучшее понимание и осознание как использовать эмоции в спорте. Сопоставительный анализ исследования состоит в попытке проанализировать различия между спортсменами и спортсменками провинции Лусака относительно эмоционального 
восприятия в выбранных показателях, таких как самосознание, самонастройка, мотивация, эмпатия, социальные умения.

Автор считает, что спортсменки обладают более высоким уровнем эмоционального восприятия, чем спортсмены. «Тест на эмоциональное восприятие», разработанный доктором Н.К. Чадха (1998) применялся по отношению ко всем участникам исследования (3о спортсменкам и 40 спортсменам). Для данного исследования был применен выбор в случайном порядке. Статистический анализ вычисления с помощью «t-критерия» показал значительную разницу в эмоциональном восприятии спортсменов и спортсменок провинции Лусака. Результаты подтвердили гипотетическую разницу в отношении эмоционального восприятия. Данные, полученные в ходе данного исследования, определили, что спортсменки более эмоционально восприимчивы, чем спортсмены. Более высокий уровень эмоционального восприятия спортсменок по сравнению со спортсменами в провинции Лусака объясняется традициями, примером общества и социальными ролями мужчин и женщин в африканской культуре Замбии.

Ключевые слова: эмоциональное; восприятие; спортсмены; женщины; мужчины. 